\title{
O acorde-Weber: uma análise sobre a identidade teórica de Max Weber
}

\author{
The Weber-chord: an analysis of Max Weber theory identity \\ through a musical metaphor
}

José D’Assunção Barros ${ }^{1}$

\begin{abstract}
Resumo
Este artigo tem por objetivo desenvolver algumas considerações acerca das relações entre Objetividade e Subjetividade na Sociologia de Max Weber e em seu pensamento historiográfico. Para guiar nossas reflexões a respeito deste sociólogo-historiador, estaremos usando a metáfora do 'acorde teórico' - uma metáfora emprestada à Música - de modo a pensar a interação entre alguns elementos que constituem a 'identidade teórica' de Max Weber. A principal obra de Weber que estaremos analisando será A Objetividade do conhecimento nas Ciências Sociais (1904), através da qual será possível desenvolver algumas considerações sobre a questão examinada.

Palavras-chave: Max Weber. Objetividade. Subjetividade.
\end{abstract}

\begin{abstract}
This article aims to develop some considerations about the relations between Objectivity and Subjectivity in the Sociology of Max Weber and in his historiographic thought. To guide our reflections about this sociologist-historian, we are using here the metaphor of the 'theory chord', a metaphor borrowed from Music, in order to think the interaction between some elements that constitute Max Weber Theory identity. The principal work of Max Weber analysed is Objectivity and Subjectivity in Social Sciences (1904), whereby it will be possible to develop some considerations about the question examined.
\end{abstract}

Keywords: Max Weber. Objectivity. Subjectivity.

\section{Oscilações Entre o Positivismo e oHistoricismo}

As propostas teórico-metodológicas de Max Weber (1864-1920) trazem um interessante problema para a Historiografia: Este sociólogo-historiador parece, para as análises historiográficas mais habituais, situar-se em uma posição intermediária entre um cientificismo tendente ao Positivismo, que investe na possibilidade de alcançar resultados objetivos e únicos para um mesmo objeto de pesquisa sob determinadas condições de construção do conhecimento, e um Historicismo que já deixa entrever claramente uma posição relativista, uma vez que admite uma complexa subjetividade do próprio sujeito de conhecimento, além da singularidade e historicidade do objeto de estudo das ciências sociais (rejeitando as generalizações e universalismos positivistas, para este caso) ${ }^{2}$. Em vista disso, não são raros os autores que situam Max Weber entre

\footnotetext{
${ }^{1}$ Professor da Universidade Federal Rural do Rio de Janeiro, nos cursos de Graduação e Mestrado, e professor colaborador do Programa de Pós-Graduação em História Comparada da Universidade Federal do Rio de Janeiro. Doutor em História pela Universidade Federal Fluminense.

${ }^{2}$ Naturalmente que as leituras sobre Weber se diversificam, e há mesmo neo-positivistas que tentam convocá-lo integralmente para os quadros do Positivismo, como Parsons (1971, p. 38-39).
} 
dois paradigmas - o Positivista e o Historicista. Por outro lado, proporemos neste artigo a utilização de um recurso novo, a metáfora do "acorde teórico", com vistas a buscar apreender a complexidade do pensamento teórico weberiano.

Um acorde, na música, é uma entidade sonora que integra diversas 'notas musicais'. Estaremos utilizando esta imagem para nos referirmos à complexidade da identidade teórica de Max Weber: um autor que assimila diversas 'notas de influência', emprestando-lhes novos sentidos, e que também integra no seu 'acorde teórico' elementos originários de paradigmas vários. Esta complexidade, contudo, Max Weber dotou de uma coerência impar, que faz sua obra ser assinalada por uma especial unidade teórico-metodológica.

Começaremos por ressaltar que o reconhecimento da complexa 'subjetividade que atinge o próprio sujeito de conhecimento', além da atenção à 'historicidade de cada objeto de estudo' pertinente às ciências sociais ${ }^{3}$, faz com que Weber se aproxime solidariamente do Historicismo, e por isto aqueles devem ser considerados os dois elementos que constituem a nota fundamental de seu acorde teórico. Dito de outra forma, esse duplo reconhecimento das intersubjetividades presentes simultaneamente no objeto da História e no sujeito que produz a História permitem que, de algum modo, possamos propor a idéia de que a base fundamental de Max Weber é o Historicismo, ou pelo menos um tipo de historicismo à maneira weberiana. Já o primeiro aspecto antes referido, o interesse em fixar a "neutralidade" como uma possibilidade e como uma exigência científica que se coloca ao cientista social, deixa entrever em Weber um traço Positivista ${ }^{4}$. A ambição de assegurar uma neutralidade científica à maneira positivista constitui, portanto, a segunda nota do 'acorde Weber', embora uma nota bem menos intensa do que a nota historicista. Outra maneira de compreender essa delicada combinação, se não quisermos utilizar a metáfora do acorde, é a já mencionada possibilidade de visualizarmos Max Weber como um autor situado entre dois paradigmas, o do Historicismo e o do Positivismo, tal como propõem alguns autores.

Deve-se considerar ainda que, em um de seus mais conhecidos textos teórico-metodológicos, o ensaio A Objetividade do conhecimento nas Ciências Sociais (1904) - escrito para integrar o editorial de abertura de uma Revista por ele dirigida - Weber chega a explicitar a sua adesão à base historicista através do reconhecimento de que, de alguma maneira, ele mesmo pertence à "escola histórica alemã"; mas faz isso sem deixar de demarcar muito claramente o seu distanciamento em relação àquele ramo realista do Historicismo que pode ser referido ao modelo rankeano ${ }^{5}$. Assume, portanto, um alinhamento em relação ao ramo mais relativista do Historicismo. Também chega, no mesmo texto, a se posicionar no âmbito dos historiadores da cultura, por oposição aos "historiadores políticos" ${ }^{6}$. Esse é o primeiro traço de sua identidade teórica abertamente assumido, mas há ainda outros.

3 Em A Objetividade do Conhecimento nas Ciências Sociais (1904), texto no qual se explicita a concepção weberiana sobre a produção do conhecimento, Max Weber prefere se referir ao conjunto das ciências sociais e humanas como "ciências da cultura", uma designação que remonta a um dos pensadores que o influenciaram: Heinrich Rickert (1863-1936). Este havia utilizado a designação já em 1899, em seu ensaio Ciências da Cultura e Ciências Naturais, no qual se refere aos dois padrões de produção do conhecimento científico.

4 Michael Löwi assim situa o que ele denomina uma démarche de Weber entre o Historicismo e o Positivismo: "sua teoria da Wertbeziehung das questões é de tendência historicista; sua teoria da Wert-freiheit (neutralidade axiológica ou "sem julgamentos de valor") das respostas é de orientação positivista" (LÖWY, 1994, p. 37).

${ }^{5}$ Objetividade do conhecimento nas Ciências Sociais foi publicado em 1904, como editorial programático da revista Arquivo para a Ciência Social e Política Social, da qual Max Weber era um dos diretores. Com relação ao aspecto ressaltado - a referência a uma adesão ao historicismo alemão - encontra-se neste texto a seguinte passagem: "Se deduzirmos as consequências do que fica dito, chegaremos a um ponto em que as nossas opiniões talvez se diferenciem, num ou noutro aspecto, das opiniões de muitos representantes eminentes da escola histórica à qual também pertencemos" (WEBER, 2008a, p.121, grifo nosso).

6 E, consequentemente, poder-se-ia reivindicar para o historiador da nossa disciplina o mesmo direito concedido ao historiador político [...] (WEBER, 2008a, p. 122). 


\section{Diálogos com os Pensamentos de Marx e Nietzsche}

À Parte as influências mais explícitas, podemos considerar que existe ainda um harmônico oculto em Weber. Muitos autores consideram a perspectiva de que boa parte da obra de Weber, ou ao menos uma parte importante, constitui uma resposta a Marx. Se a posição política de Weber o distancia do Materialismo Histórico, inegavelmente os problemas levantados por Marx e Engels constituíram perturbações importantes que motivaram o sociólogo alemão a buscar suas próprias respostas para determinadas questões sociais, para a questão da posição do cientista na sociedade, para os aspectos que concernem à teoria e à metodologia envolvidas na produção de conhecimento em ciências sociais. O diálogo de confronto em relação a Marx está, por vezes, explícito no estilo polemista tão típico de Weber, mas também não serão raras as situações em que este diálogo estará implícito na utilização de um vocabulário de referência ${ }^{7}$. Naturalmente, há pontos mais claros de confronto entre as posições de Weber e certas tendências apresentadas pelo Materialismo Histórico de sua época, sendo a principal delas a rejeição weberiana do determinismo, seja no aspecto sincrônico (a base que determina a superestrutura), seja no seu aspecto diacrônico (a possibilidade de se falar em um curso determinável dos processos históricos). Ao mesmo tempo, existe um ambiente de discussão em comum.

À partida, tal como ocorre com Marx, a preocupação de Max Weber com a base econômica da sociedade mostra-se central em boa parte dos seus trabalhos ${ }^{8}$. Ao mesmo tempo, a Alemanha, na época em que Weber exercia a sua atividade acadêmica, estava particularmente agitada por movimentos sociais, e por isso o sociólogo alemão sentiu-se chamado a trazer uma resposta a estas inquietações sociais, o que o levou a dialogar implicitamente com o Marxismo, uma vez que uma vertente do Materialismo Histórico vinha sendo adotada por algumas das principais lideranças do movimento operário alemão nas primeiras décadas do século XX. Por fim, tal como para Marx, a questão da vida humana sob o Capitalismo foi certamente um dos grandes temas de estudo de Max Weber. Em Weber, pode-se mesmo dizer que o grande tema que estará sempre presente, ou como objeto direto de estudo ou como preocupação e valor que motiva a escolha de uma diversidade de outros temas históricos, é o do moderno Capitalismo e de suas relações com uma forma específica de racionalidade e comportamento que ele mesmo produz ${ }^{9}$. As escolhas e motivações de Max Weber e Karl Marx, portanto, de alguma

\footnotetext{
${ }_{7}$ No ensaio Causas Sociais do Declínio da Cultura Antiga (1896), Weber utilizará expressões tipicamente marxistas, como "infraestrutura" e "superestrutura", mas sem incorporar os pressupostos deterministas.

${ }^{8}$ Em cada uma das 4 fases da intensa produção bibliográfica de Max Weber, que se alternam com outras fases de vazio produtivo, há pelo menos uma obra importante que traz a Economia ao centro da análise. A fase inicial, inaugurada em $1891 \mathrm{com}$ História Agrária de Roma e sua importância para o Direito Público e Privado, passa mais tarde por um estudo sobre O Estado Nacional e a Política Econômica (1895), e conduz-se ao ensaio sobre as "causas sociais do Declínio do Mundo Antigo" (1896), no qual Weber examina o declínio do Império Romano relativamente à desagregação econômico-social das cidades, do trabalho escravista e do comércio externo. Depois, Weber conhece sua primeira e mais grave crise produtiva, até que, 5 anos depois, retoma seu trabalho produtivo em outras três fases nas quais há sempre um lugar importante para a análise econômica. Na fase produtiva de 1903 a 1906 destaca-se Ética Protestante e Espírito do Capitalismo (1904-1905); e na fase de 1911 a 1913, Max Weber escreve Economia e Sociedade. Na terceira e última fase produtiva, que se situa entre os anos 1916 e 1919, desenvolve três estudos em torno da temática da "ética econômica das religiões mundiais". A Religião, aliás, foi outro tema que atraiu a atenção científica de Max Weber, e não raro o sociólogo alemão tratou essa temática em diálogo com os aspectos econômicos.

9 Mesmo quando aborda temas relacionados à Antiguidade, como em Condições Agrárias da Antiguidade (1909), não será raro encontrarmos passagens em que Weber explicita suas preocupações em examinar as relações do Capitalismo ou de alguma formação econômica que possa ser abordada em analogia com certo padrão de comportamento e racionalidade. No estudo em questão, além da adaptação à Antiguidade da noção de "Capital”, por vezes de maneira anacrônica, Weber também compara a burocracia antiga e a burocracia moderna, avaliando a sua influência sobre a economia da época.

10 Desde a primeira metade do século, com a obra Weber e Marx, de Karl Löwith (1933), surgiram tentativas de compreender interseções possíveis entre Weber e Marx, apesar de suas posições políticas bem diferenciadas e do debate nas ciências sociais que tendeu a opor radicalmente estes dois autores.
} 
maneira se aproximam, e não é por acaso que muitos autores se empenharam não apenas em examinar o contraste entre estes dois autores paradigmáticos, como também em avaliar as suas semelhanças e pontos de possíveis diálogos ${ }^{10}$. Vale lembrar que Weber registra, também no texto "Objetividade do conhecimento nas Ciências Sociais", uma passagem particularmente elogiosa em relação a Karl Max, mas sempre desconfiada em relação aos usos equivocados que possam ser feitos de suas formulações teóricas. No início, desculpa-se por não ter abordado Marx especificamente naquele texto, mas prometendo concretizar a partir dali um verdadeiro programa de estudos sobre o pensamento de Marx e os desdobramentos do Materialismo Histórico:

\begin{abstract}
Intencionalmente, deixou de ser demonstrada a nossa concepção no exemplo de longe o mais importante de construções de tipo ideal: o de Marx. E isto para não complicar a exposição com a introdução das interpretações de Marx, e também para não antecipar as futuras discussões de nossa revista, nas quais se submeterão a uma análise crítica as obras escritas sobre este grande pensador ou inspiradas nas suas doutrinas. Limitamo-nos a constatar aqui que todas as 'leis' e construções do desenvolvimento histórico especificamente marxistas naturalmente possuem um caráter de tipo ideal, na medida em que sejam teoricamente corretas. Quem quer que tenha trabalhado com os conceitos marxistas, conhece a eminente e inigualável importância heurística destes tipos ideais, quando utilizados para compará-los com a realidade, mas conhece igualmente o seu perigo, logo que são apresentados como construções com validade empírica ou até mesmo como tendências ou 'forças ativas' reais (o que, na verdade, significa metafísicas) (WEBER, 2008a, p. 118-119).
\end{abstract}

Max Weber atribui às formulações teóricas de Karl Marx o estatuto de "tipos ideais" (conceito que se refere a um recurso metodológico weberiano no qual nos deteremos em maior profundidade mais adiante), e rejeita veementemente as intenções de compreendê-las como construções que anunciam algo como as "leis da história". O principal ponto de confronto entre o 'acorde teórico' de Max Weber e este seu harmônico oculto, o Materialismo Histórico de Karl Marx, encontra-se certamente na rejeição weberiana da determinação unilinear da esfera econômica sobre as demais esferas da vida social (as esferas política, religiosa, jurídica, artística e outras). Hoje em dia, com mais de um século de rediscussões sobre a questão do determinismo a partir das diversas correntes teóricas que surgiram no interior do próprio Materialismo Histórico - da Escola de Frankfurt à Escola Inglesa do Marxismo, apenas para mencionar duas das mais proeminentes posturas críticas - as posições de Weber parecem se aproximar de algumas correntes marxistas que também rejeitaram o padrão de determinação unilinear da "base" sobre a "superestrutura". Na época de Weber, no entanto, certos setores do Materialismo Histórico haviam engessado em doutrina alguns princípios com os quais Marx trabalhara de modo bem mais flexível. O chamado marxismo-leninismo estava a propor uma variação do materialismo histórico para uso político; não tardaria a surgir a proposta stalinista sobre um determinismo econômico que deveria reger a noção de uma história que se encadeava em etapas necessárias. Max Weber, em 1905, estava particularmente preocupado em mostrar que as diversas esferas da vida social detinham um potencial de autonomia e uma lógica específica, e que nos vários momentos históricos estas várias esferas da vida social poderiam se articular de modos diferentes umas às outras. Dessa forma, o sociólogo alemão estava preocupado em restituir a complexidade ao jogo de interações dinâmicas que se estabelece entre as várias esferas - econômica, política, jurídica, artística, religiosa - e isso de acordo com cada contexto histórico, que pode trazer para a centralidade estas ou aquelas esferas e também apresentar novas formas de articulações entre elas. Esta defesa da complexidade histórica esteve por trás da obra mais conhecida de Max Weber: A Ética Protestante e o Espírito do Capitalismo (1905), e não há como negar que este ensaio introduz o diálogo dissonante de Weber com um dos seus harmônicos ocultos, o Materialismo Histórico. 
Existe ainda, por outro lado, outro aspecto fundamental que aproxima Weber mais de Marx do que dos tradicionais sociólogos positivistas, tais como Comte ou Durkheim. Enquanto Augusto Comte trabalhava com a perspectiva de uma "conciliação de classes", a ser conduzida sob a égide da burguesia industrial, e ao mesmo tempo em que Durkheim via na "divisão social do trabalho" uma forma de "suavização da luta pela vida" 11 , Weber será sempre um analista do conflito. $\mathrm{Na}$ análise social, teremos entre alguns de seus temas preferidos os esquemas e formas de dominação e de perpetuação do poder, assim como a luta permanente do homem e dos grupos humanos no interior da sociedade e entre sociedades distintas, ou a própria luta pela existência em si mesma; na reflexão teórico-metodológica, teremos no reconhecimento e na análise dos valores irreconciliáveis uma das tônicas da perspectiva weberiana do conhecimento, apesar do dedicado empenho em buscar e sustentar a possibilidade de chegar a um tipo de conhecimento "objetivo" para as ciências sociais. Seja no que se refere ao âmbito social e político, à esfera das idéias ou à própria vida diária, a "luta" é um conceito inerente à análise weberiana. Essa perspectiva de aceitação do conflito como instância inevitável da vida humana e da história, embora dotada de suas especificidades para cada caso, aproxima Marx e Weber, ou também este último de alguns dos historicistas franceses do período da Restauração, como Thierry e Guizot, que já viam as "classes sociais em luta" como uma instância primordial a ser examinada pela História ${ }^{12}$. Por fim, a perspectiva weberiana de um devir atravessado por conflitos também aproxima o sociólogo de um filósofo que, àquela altura, já tinha se tornado bem conhecido: Friedrich Nietzsche. Seria este mais um de seus harmônicos ocultos? ${ }^{13}$ De todo modo, o "poder" e a luta pelo poder, suas formas de perpetuação e de expressão, o papel do Estado nas sociedades modernas, tornam-se temas centrais para Max Weber. A atenção ao "político", ao lado da preocupação com a "economia" e da inclinação aos estudos sobre as formas de "religiosidade" e outros aspectos culturais, constituem a tríade temática fundamental de Max Weber, vindo a constituir uma nota proeminente do seu acorde teórico.$^{14}$

\footnotetext{
11 ver Cohn (2008, p. 18).

${ }^{12}$ Em contrapartida, Max Weber tendia a sustentar que o ponto de partida da análise sociológica deveria ser a ação dos indivíduos ou do grupo dos indivíduos. Melhor situando este aspecto em relação à própria nomenclatura weberiana, a análise sociológica deve partir dos "agentes" que encaminham as "ações sociais". Gabriel Cohn, em sua "Apresentação" a uma seleção de textos de Weber, transcreve uma passagem de uma carta de Weber a Robert Liefmann, na qual o sociólogo alemão sustenta que "também a Sociologia somente pode ser implementada tomando-se como ponto de partida a ação do indivíduo ou de um número maior ou menor de indivíduos, portanto de modo estritamente individualista quanto ao método" (COHN, 2008, p. 25). A importância que Max Weber dará ao conceito de "ação social" - buscando compreendê-la de acordo com o "agente" e com tipo de "motivo" que desencadeia a "ação", em cada caso - sintoniza-se com esta perspectiva.

13 Entre encaixes e desencaixes, Nietzsche, da mesma forma que Marx, pode ser indicado como um harmônico - uma sonoridade oculta - no acorde teórico de Max Weber. Tal como ressalta Gabriel Cohn (1979), Weber considerava Marx e Nietzsche como os autores decisivos de sua época, e era preciso, portanto, tomar posição diante do pensamento de cada um deles (já Durkheim é francamente ignorado pelo sociólogo alemão). Em certa passagem de Ciência como Vocação (1919), Weber evoca a autoridade da crítica nietzscheniana contra o positivismo ingênuo do progresso científico (WEBER, 1993, p. 42), e o seu "desencantamento do mundo" remete à imagem nietzscheniana da "morte de Deus". Sobre eventuais e possíveis influências de Nietzsche em Weber, ver Owen (1994). Naturalmente que são ambíguas as interações possíveis entre o pensamento de Nietzsche e a identidade teórica de Max Weber, já que este último apresenta em seu acorde teórico uma 'nota neo-kantiana' dotada de expressiva intensidade. Todavia, todo pensamento é complexo. Raros autores conseguem influenciar um outro autor como uma 'totalidade'. As 'notas de influência' de um acorde teórico não são mais do que o nome indica: determinados aspectos do pensamento de um autor é que podem influenciar a 'identidade teórica' de um outro, e não necessariamente um autor inteiro, ou tampouco a totalidade de um sistema de pensamento.

$14 \mathrm{O}$ poder e a economia frequentemente se imbricam na análise weberiana. Um dos exemplos mais evidentes, em seu próprio título, é o ensaio de 1895 intitulado O Estado Nacional e a política econômica. Neste texto, Max Weber procurará mostrar
} 


\section{Diálogos entre o Presente e o Passado}

Traço importante da 'identidade teórica' weberiana, de especial interesse para compreender a sua concepção historiográfica, é o que se refere à necessidade de um diálogo permanente entre o Presente e o Passado que está sendo analisado pelo historiador ou pela sociologia histórica. Este ponto corresponde a um aspecto importante de certos setores do Historicismo, e também o encontraremos amiúde nas várias perspectivas teóricas ligadas ao Materialismo Histórico. Em Max Weber, será possível surpreender sempre, por trás das escolhas temáticas e problemáticas, a preocupação com alguma questão do presente do pesquisador que se impõe como motivação primordial para a determinação do tema da pesquisa e para o encaminhamento da mesma. Weber refletirá explicitamente a esse vrespeito, conforme veremos a seguir, e também praticará este diálogo de temporalidades na sua própria atividade de pesquisa e de reflexão sobre temáticas específicas. Não é por acaso que a primeira fase de sua produção, que trará títulos como A História Agrária de Roma e sua importância para o Direito Público e Privado (1891) e Causas Sociais do Declínio da Cultura Antiga (1896), enquadra cronologicamente o período no qual realizou uma minuciosa pesquisa acerca da situação agrária da Alemanha (COHN, 2008, p. 18). Não raro, o sociólogo Max Weber estará estudando um tema que reverbera no tema histórico que está sendo examinado concomitantemente pelo historiador Max Weber, e vice-versa. A escolha ou constituição de um objeto histórico, conforme veremos com a próxima nota, é para Max Weber ditada pelos valores do tempo presente e pelos interesses e pontos de vista do sujeito que produz o conhecimento, e o pesquisador das ciências humanas deve assumir esta ligação com plena consciência, o que certamente o vincula mais uma vez à perspectiva historicista.

Essa questão, aliás, é tão importante quanto delicada e complexa em Max Weber. Para o sociólogo alemão, o reconhecimento da repercussão dos valores e posicionamentos éticos do pesquisador nos primórdios de um trabalho científico não significa que novas decisões éticas possam ser geradas como produtos finais do trabalho científico, e tampouco que a ciência deva ser colocada a serviço da política. Ou, ao menos, os resultados de um trabalho científico não podem ser atrelados ou determinados pelos interesses políticos, não podem ser evocados como imperativos para impor tomadas de posição com relação a questões políticas. Tal como discutirá Weber em dois textos intitulados Ciência como Vocação e Política como Vocação (1919), a postura do cientista diferenciase radicalmente da postura do político de ação, do homem prático. Embora o cientista tenha seu trabalho interferido inicialmente por juízos de valor, as suas conclusões não podem produzir juízos de valor, o que já ocorre necessariamente nos encaminhamentos a serem tomados pelo homem que exerce a atividade política. De igual maneira, se a ciência é interferida, à partida, pela Política (pelas relações de poder e posicionamentos perante os vários poderes), na saída, a Ciência

como tanto o Estado em si mesmo, como a política econômica, são expressões da luta pela direção da sociedade alemã. Já a concomitante análise do conflito entre alemães e poloneses, lutando pela sua própria existência social nas fronteiras da Prússia, será instrumentalizada por Weber para sustentar sua própria posição com relação à necessidade de autonomia do estado nacional na sua contraposição a outros. Sobre estes aspectos, ver a análise de Gabriel Cohn na sua "Apresentação" para a coletânea de textos de Weber (COHN, 2008, p. 17-18). Se uma das mais freqüentes escolhas temáticas de Weber foi a de investigar a conexão entre o "político" e o "econômico", o sociólogo alemão também não deixou de trabalhar na conexão entre a religiosidade e a economia. O seu conjunto de estudos sobre A Ética Econômica das Religiões Mundiais atesta isto. Weber estudou em profundidade o hinduísmo e budismo (formas religiosas da Índia), e também o confucionismo e taoísmo (formas chinesas). Por outro lado, a conexão entre religiosidade e economia também está presente em Ética Protestante e o Espírito do Capitalismo (1905), obra na qual propõe a célebre hipótese de que haveria uma relação de causalidade entre a emergência de uma nova forma conduta surgida da religiosidade protestante e a conduta racional capitalista na esfera econômica. A Sociologia da Religião, enfim, foi uma das modalidades sociológicas nas quais Max Weber terminou por se constituir em uma das principais autoridades reconhecidas por aqueles que se dedicam ao estudo social das formas religiosas. 
deve se considerar apolítica. Ademais, a ciência está capacitada para dizer o que se "pode fazer", mas não o que se "deve fazer". Em Ciência como Vocação, Weber registra um exemplo:

Certamente uma coisa é tomar uma posição política prática, e outra coisa é analisar cientificamente as estruturas políticas e as doutrinas dos partidos. Se, em uma reunião política, discute-se a democracia, não se faz segredo da posição pessoal adotada e a necessidade de tomar partido de maneira clara se impõe, então, como um dever maldito. As palavras empregadas em uma ocasião como esta não são mais instrumentos de análise científica, mas constituem apelo político destinado a solicitar que os outros tomem posição. Longe estão de serem relhas de arado para remexer o campo imenso do pensamento contemplativo, constituindo-se em gládios para conter os adversários, ou, em outras palavras, meios de combate. Empregar palavras dessa maneira numa sala de aula seria torpe. Em um curso universitário, quando se manifesta a intenção de estudar, por exemplo, a democracia, procede-se ao exame de suas diversas formas, do devido funcionamento de cada uma delas, e indagase pelas conseqüências que uma e outra acarretam. A seguir, à democracia opõem-se as formas nãodemocráticas da ordem política e tenta-se levar essa análise até a medida que o próprio ouvinte se ache em condições de encontrar o ponto a partir do qual poderá tomar posição, fundamentado em seus ideais básicos (WEBER, 1993, p. 45-46) ${ }^{15}$.

\section{O Viés Neo-Kantiano}

A "nota de topo" do 'acorde Max Weber', sob a qual se desenvolve uma harmonia que termina por assegurar a singularidade de uma obra extremamente original no que concerne à maneira de entender a produção do conhecimento científico, é a da 'filosofia neo-kantiana'"16 . Dela, Max Weber extrairá em especial a sua distinção entre "fatos" e "valores", um aspecto que veremos ser bastante importante para a concepção de Weber sobre o jogo entre objetividade e subjetividade. Neste aspecto em particular, o autor que mais influenciou Weber, e que neste sentido pode ser considerado um dos harmônicos presentes na nota neo-kantiana do 'acorde Weber', foi Heinrich Rickert (1863-1936).

Rickert foi um dos fundadores da chamada "Filosofia dos Valores", e também um dos membros de maior relevo da Escola de Baden, que também contou em seus quadros com o nome de Wilhelm Windelband (1848-1915). Ao ressaltar que as ciências humanas e as ciências naturais não se distinguem pelo tipo de objetos de estudo a que se dedicam, mas sim pelo tipo de procedimentos adotados, Rickert acompanha a divisão que já havia sido proposta por Dilthey e Windelband entre as ciências naturais e as ciências humanas no que concerne ao padrão metodológico. Ele reforça a posição destes autores para os quais as ciências naturais utilizariam métodos nomotéticos (voltados para a descoberta de leis), e as ciências humanas tenderiam ao emprego de métodos ideográficos (aqueles que buscam descrever ou apreender os fenômenos singulares) ${ }^{17}$. Por outro lado, enquanto Dilthey situava a oposição entre os dois tipos de ciência nos termos de "ciências naturais" e "ciências do espírito", Rickert preferiu opor ao "natural" ao "histórico" (ou ao "cultural"), o que lhe permitiu refletir de maneira mais rica acerca dos campos de saber intermédios como o

\footnotetext{
15 A tomada de posição, nesta e em outras passagens, coloca-se como uma escolha que se dá no plano ético, e nunca como decorrência de um imperativo científico. Em Objetividade do Conhecimento nas Ciências Sociais (1904), Weber dirá: "uma ciência empírica não está apta a ensinar a quem quer que seja aquilo que 'deve fazer', mas sim, apenas aquilo que 'pode fazer' e - em certas circunstâncias - aquilo que "quer fazer"”.

${ }^{16}$ Weber explicita este aspecto de sua identidade teórica em Objetividade do conhecimento nas Ciências Sociais: "Para aquele que [como ele mesmo] desenvolve até às suas últimas consequências a idéia fundamental da moderna teoria do conhecimento, baseada em Kant, segundo a qual os conceitos são e apenas podem ser meios intelectuais para o domínio espiritual do empiricamente dado, a circunstância de que os conceitos genéticos rigorosos são tipos ideais não constitui uma razão para que se oponha à sua construção. Para ele, dever-se-ia inverter a relação entre conceito e trabalho historiográfico: [...] os conceitos não são a meta, mas meios para o conhecimento das relações significativas sob pontos de vista individuais" (WEBER, 2008a, p. 122).
} 
da Psicologia, que embora tivesse por objeto de estudo a alma humana, estaria em busca de leis como as diversas "ciências naturais"18 .

Para além dessa discussão da especificidade das ciências humanas frente às ciências naturais, a principal contribuição de Rickert foi chamar atenção para o fato de que qualquer objeto de estudo nas ciências humanas, já de saída, é sempre definido por "valores" já trazidos pelo pesquisador 19. Esta idéia se mostrará basilar para Max Weber, e ele irá aprofundá-la em novas direções: seria a partir de valores relacionados à nacionalidade, à religiosidade, e a outros aspectos, que um tema é escolhido para pesquisa. Portanto, não há neutralidade possível já desde a semente mais primordial que irá desencadear a produção de um conhecimento no âmbito das ciências humanas. Veremos mais adiante a solução que Max Weber dá para este dilema: como produzir um conhecimento objetivo, se já desde a própria escolha do seu objeto de estudos o pesquisador das ciências humanas e sociais está atravessado por subjetividades que orientam seus interesses de estudo? Essa pergunta, e a resposta que se pode dar a ela, repercute como um insistente baixo ostinato no acorde teórico de Max Weber.

\section{Aspectos Metodológicos}

Devemos lembrar uma nota importante no acorde de Weber: o 'comparativismo'. Frequentemente, Max Weber trabalhou metodologicamente com a comparação, além de também revelar uma tendência a escolher temas que podem ser classificados no âmbito da 'sociologia comparada' ou da 'história comparada'. Desenvolveu pesquisas, por exemplo, a respeito das cidades e outros tipos de formações urbanas em períodos diversificados, que vão da Antiguidade aos tempos contemporâneos. Interessou-se também pelos padrões de religiosidade, pelas formas de dominação política, e por diversos outros assuntos que, de alguma maneira, sempre pôde abordar pelo método comparativo.

A questão que mais nos interessa no momento, tal como a proposta estabelecida no início deste artigo, é a da interação entre subjetividade e objetividade no processo de produção do conhecimento, na História e nas demais ciências humanas. É nesta questão que iremos nos deter, pois a obra de Max Weber é extremamente rica em muitos outros aspectos e requereria muito mais espaço para discussão. Para a questão que nos interessa, é oportuno considerar que Max Weber procura dar conta da conquista de uma objetividade efetiva no processo de conhecimento através daquilo que, conforme o próprio sociólogo alemão postula, constituiria uma "neutralidade ética". Em algumas oportunidades, Weber se referirá a esta neutralidade ética como um "dever elementar de autocontrole científico" (WEBER, 2008a, p. 114). Este é o ponto exato no qual a abordagem weberiana e as ambições positivistas de neutralidade parecem se tocar.

\footnotetext{
17 Na verdade, aprimorando ainda mais a oposição proposta e dotando-a de uma marca pessoal que o fará distinguir-se tanto de Dilthey como de Windelband, para Rickert, o que estaria realmente na base de oposição entre estes dois padrões metodológicos que acompanham os dois tipos de ciência - as nomotéticas e as idiográficas - seria contraposição mais visceral entre "ciências generalizantes" e "ciências individualizantes", particularmente no sentido de que, se ambos os tipos de ciências produzem conceitos, os conceitos produzidos pela História e outras 'ciências idiográficas' seriam sempre e necessariamente revestidos de "valor", diferentemente dos "conceitos generalizantes" das ditas ciências naturais.

18 Os "territórios intermédios" do saber, situados na mediação ou no entrecruzamento anfíbio dos dois tipos de ciências, são discutidos por Rickert em Ciências Culturais e Ciências Naturais (RICKERT, 1922, p. 22).

19 Rickert dá um passo importante no que se refere ao reconhecimento dos valores que interferem na produção do conhecimento nas ciências humanas. Mas, ao contrário de Max Weber, ainda irá se amparar da idéia de que existiriam alguns poucos valores universais, como a "verdade" ou a "liberdade", e que estes valores, aceitos por todos, permitiriam a constituição de uma certa base de objetividade. Weber rejeitará a idéia de que existam mesmo alguns poucos valores universais, e por isso buscará assegurar a objetividade por outras vias.
} 
Posto isto, a riqueza e complexidade da 'identidade teórica' weberiana encontra-se no fato de que há nela muito mais pontos de contato com o Historicismo do que com o Positivismo. Para retomar a nossa metáfora do 'acorde teórico', podemos dizer que a 'nota historicista' é muito mais intensa em Weber do que a sua discreta 'nota positivista'. É assim que, sobre a consideração (historicista) acerca da necessidade de apreender o objeto social de estudo em sua singularidade, há textos diversos nos quais Weber estabelece como objetivo das ciências sociais o estudo da realidade sócio-cultural tal como ela é, em sua singularidade e originalidade. Tratase de considerar tanto a historicidade do processo ou objeto examinado, como de retratar a estrutura atualizada e específica das relações sociais que o envolvem (WEBER, 1965, p. 19). Além disto, e também firmando aqui a sua posição distanciada em relação a posturas mais marcadamente positivistas, Weber sustenta que o objetivo de uma ciência social não é atingir uma apreensão total da realidade social, encontrando um sistema rigoroso de leis que se mostre aplicável a tudo, mas sim examinar a cada vez um fragmento delimitado da realidade que, por sua vez, é resultado de um processo de seleção e interesse no qual interfere de algum modo a subjetividade do cientista social. Isto posto, o uso do método comparativo abre também a possibilidade de lançar transversalmente um olhar sobre fragmentos e contextos diversos, tal como o próprio Weber fez ao estudar a cidade através do tempo. Desse modo, em Weber o cientista social direciona um olho para a apreensão da singularidade do fragmento de realidade examinado, e outro olho para captar aquilo que se repete ou que se diferencia em uma série.

No que se refere às suas considerações mais gerais acerca do Método, Weber inscreve-se perfeitamente na tradição que vai encontrar em Wilhelm Dilthey (1833-1911) o seu desenvolvimento mais bem acabado entre os filósofos historicistas do século XIX. Os conhecimentos da natureza e da sociedade, como já se disse, são assumidos como de tipo diferente um do outro, e que, portanto, requerem metodologias, ou mesmo posturas metodológicas bem diferenciadas. Vigora no plano mais geral da metodologia weberiana a oposição entre as posturas da "explicação" e da "compreensão", conforme discutidas por Dilthey, e no plano técnico mais específico afirma-se o contraste entre a tendência das ciências naturais ao quantitativo-mensurável e a tendência das ciências sociais e humanas à análise qualitativa, embora essa oposição não seja tão rigorosa, já que tanto o quantificável também pode ser encontrado entre os fenômenos sociais, como o qualitativo pode estar eventualmente referido às ciências naturais. Com relação ao sentido mais específico da "compreensão" como postura fundamental proposta por Max Weber para as ciências sociais, o método compreensivo teria por objetivo apreender o "sentido" de cada ação humana, extrair destas o seu conteúdo simbólico, compreendê-las como carregadas de sentido, e não como meros elos em uma cadeia de causas e efeitos. Trata-se de examinar, em uma palavra, a sua interioridade, o que de algum modo já o diferencia da postura durkheimiana de encarar os fatos sociais como "coisas".

\section{Objetividade e Subjetividade}

Para a nossa discussão acerca do contraste entre Objetividade e Subjetividade nas ciências humanas, interessa-nos particularmente a mediação que se estabelece, na obra de Max Weber, entre o reconhecimento historicista da subjetividade do cientista social e a ambição positivista de neutralidade científica em última instância. Esses aspectos acham-se bem desenvolvidos em alguns textos de Max Weber, tal como no ensaio de 1904 intitulado A Objetividade do Conhecimento nas Ciências e Políticas Sociais (1904). Examinaremos esta questão em maior profundidade, uma vez que aqui, ultrapassando a nota neo-kantiana que lhe fora transmitida por Heinrich Rickert, aparece toda a originalidade do pensamento de Max Weber: os "valores" determinam inevitavelmente as "questões" da investigação; mas as "respostas" devem ser 
inteiramente "livres de julgamentos" (WEBER, 2008a, p. 99-100) $)^{20}$.

Apesar de admitir a subjetividade do sujeito de conhecimento, para Max Weber seria possível ao cientista social assegurar certo nível de 'objetividade' relativo ao seu objeto através do Método e da prática de um autoconhecimento, que lhe permitiriam separar conceitos de preconceitos ${ }^{21}$. Por outro lado, vale lembrar que, na esteira de Kant, Max Weber tinha a convicção de que todo conhecimento é parcial, produzido por certo padrão que o historiador lança sobre o seu objeto com vistas a conhecê-lo. Em A Ética Protestante e o Espírito do Capitalismo (1904-1905), ele tematiza uma relação entre este dois termos (a "ética protestante" e o "espírito do capitalismo"), de modo que o conhecimento se produz precisamente nesta relação. Em diversos ensaios, além deste, é a relação entre "religiosidade" e "economia" o que confere o recorte problemático que irá impor uma direção ao problema ${ }^{22}$, mas em outros, o problema é o declínio de uma civilização ou cultura, ou a relação entre as formas de criação artística e as demais esferas da vida social ${ }^{23}$. Nestes e em outros exemplos, a problemática construída pelo historiador ou cientista social mostra-se fundamental para a definição do que este pesquisador poderá enxergar em uma determinada realidade ou base empírica examinada. Todavia, Weber avança em relação ao que foi dito e trabalha com o reconhecimento de que existem "valores" que motivam o próprio desejo e possibilidade do pesquisador pensar e aplicar determinada problemática a certo campo de estudos. Sem as "idéias de valor", o que inclui as crenças pessoais, o pesquisador não estaria motivado ou mesmo capacitado para formular uma problemática (a não ser que decalcasse literalmente os valores de um outro) e muito menos teria meios para sequer selecionar, de maneira coerente, os elementos de uma realidade que se apresenta, à apreensão humana, extremamente complexa, múltipla, ou mesmo caótica:

Por certo que sem as idéias de valor do investigador não existiria qualquer princípio de seleção nem conhecimento sensato do real singular e, assim como a crença do pesquisador na significação de um conteúdo cultural qualquer resultaria completamente desprovido de sentido todo o estudo do conhecimento da realidade individual, também a orientação da sua convicção pessoal e a difração dos valores no espelho da sua alma conferem ao seu trabalho uma direção. $\mathrm{E}$ os valores a que o gênio científico refere os objetos de sua investigação poderão determinar a 'concepção' que se fará de toda uma época. Isto é, não só poderão ser decisivos para aquilo que, nos fenômenos, se considera 'valiosos', mas ainda para o que passa por ser significativo ou insignificante, 'importante' ou 'secundário' (WEBER, 2008a, p. 98).

\footnotetext{
${ }^{20}$ Podemos evocar aqui as palavras Michael Löwi a respeito da concepção weberiana (LÖWY, 1994, p. 37), “os valores [na proposta weberiana] determinam as questões da investigação, mas as respostas devem ser estritamente Wert-frei; o objeto de pesquisa foi determinado a partir de um ponto de vista valorativo, mas a démarche concreta da pesquisa científica sobre este objeto é submetida a regras objetivas e universais, a um tipo de conhecimento de validade absoluta; os valores forjam os instrumentos conceituais, mas a forma de utilizá-los no estudo científico da causalidade é regida por normas gerais". Löwi cita ainda uma célebre frase de Max Weber em seu ensaio em que discute "a objetividade científico-social": "na esfera das ciências sociais, uma demonstração científica, metodicamente correta, que pretende ter atingido seu objetivo, deve poder ser reconhecida como exata da mesma maneira por um chinês ...", apesar de que este "não tenha nenhuma sensibilidade, interesse ou simpatia por nossos valores éticos e culturais" (WEBER apud LÖWI, 1994, p. 38).

${ }^{21}$ É interessante observar que esta "objetividade" que se atinge ao final do trabalho é sempre colocada entre aspas por Weber, o que é explícito no próprio título do ensaio A 'Objetividade’ do conhecimento nas Ciências Sociais (1904).

22 O conjunto de estudos sobre A Ética Econômica das Religiões Mundiais, que recorta para as religiões da Índia e da China a mesma relação que já havia sido trabalhada em Ética Protestante e Espírito do Capitalismo (1905), constitui mais um exemplo.

23 Temos como exemplo da primeira problemática indicada o ensaio Causas Sociais do Declínio da Cultura Antiga (1896), e como exemplo da segunda o ensaio Fundamentos Racionais e Sociológicos da Música (1911).
} 
Com relação a esse aspecto, poderemos já adentrar o âmago da problemática weberiana sobre o conhecimento. A perspectiva fundamental em Weber no que tange à busca de uma objetividade científica é a de que a escolha de um problema ou objeto de estudo é essencialmente subjetiva, guiada por interesses do indivíduo produtor de conhecimento de acordo com o horizonte de expectativas que lhe é oferecido pela sociedade, mas também em função dos valores que adquiriu no decorrer de suas próprias vivências e trajetória intelectual. Posto isto, uma vez selecionado subjetivamente o objeto de estudo, e definidas as condições de produção do conhecimento, para cuja delimitação também interferem fatores subjetivos do pesquisador, este poderia iniciar a sua prática de pesquisa e produção do conhecimento sob o signo da 'objetividade', valendo-se das normas de cientificidade reconhecidas pela comunidade de especialistas ligados ao seu campo de saber e policiando-se a cada instante,de modo que se assegurasse uma "objetividade final".

\footnotetext{
É evidente, no entanto, que não devemos deduzir de tudo isto que a investigação científico-cultural apenas conseguiria obter resultados 'subjetivos', no sentido em que são válidos para uns, mas não para outros. O que varia é o grau de interesse que se manifesta por um ou por outro. Por outras palavras: apenas as idéias de valor que dominam o investigador e uma época podem determinar o objeto de estudo e os limites desse estudo. No que se refere ao método de investigação - o 'como' - é o ponto de vista dominante que determina a formação dos conceitos auxiliares de que se utiliza; e quanto ao modo de utilizálos, o investigador encontra-se evidentemente ligado às normas de nosso pensamento. Porque só é uma verdade científica aquilo que pretende ser válido para todos os que querem a verdade (WEBER, 2008a, p. 99-100).
}

Com a ambição de conquistar, ao final do processo de produção do conhecimento, um resultado que seria "objetivo", aceito universalmente, e mesmo no que se refere à pretensão de assegurar ao pesquisador um certo halo de neutralidade e distanciamento, a perspectiva weberiana já parece dialogar mais uma vez com o Positivismo Clássico. A posição teórica de Max Weber no que se refere à produção do conhecimento oscila de maneira original e criativa entre estes dois pólos paradigmáticos que são o Historicismo e o Positivismo ${ }^{24}$. Aproxima-se do Historicismo no reconhecimento dos vários níveis de inter-subjetividades; afasta-se dos setores mais relativistas ligados a este paradigma e se aproxima do Positivismo quando adota a perspectiva de pretensão de "distanciamento e objetividade final" do cientista social (a "neutralidade" possível à produção do conhecimento social, embora em Weber esta seja relativa e apenas alcançável no último instante da operação historiográfica). Por fim, afasta-se mais uma vez do Positivismo, quando desconsidera a busca de leis gerais como objetivo das ciências sociais, embora admita a importância de uma reflexão sociológica em termos de leis tomadas como meios para uma aproximação do "socialmente real" 25 .

\footnotetext{
${ }^{25}$ Weber dirá: "Para as ciências da natureza as leis são tanto mais importantes e valiosas quanto mais geral é a sua validade. Para o conhecimento das condições concreta dos fenômenos históricos as leis mais gerais são frequentemente as menos valiosas, por serem as mais vazias de conteúdo. Isso porque quanto mais vasto é o campo abrangido pela validade de um conceito genérico isto é, quanto maior a sua extensão -, tanto mais nos afasta da riqueza da realidade, posto que, para poder abranger o que existe de comum ao maior número possível de fenômenos, forçosamente deverá ser o mais abstrato e pobre de conteúdo. No campo das ciências da cultura, o conhecimento do geral nunca tem valor próprio.” (WEBER, 2008a, p. 96). Da mesma forma, Weber chamará atenção para o fato de que a busca de leis não pode ser um objetivo das ciências humanas, mas apenas um meio para produzir este tipo de conhecimento: "[...] o conhecimento das leis sociais não é um conhecimento do socialmente real, mas unicamente um dos diversos meios auxiliares que o nosso pensamento utiliza para este efeito" (WEBER, 2008a, p. 96).

${ }^{24} \mathrm{Um}$ dos textos de Max Weber que explicitam com maior clareza a sua teoria sobre a produção do conhecimento foi publicado em 1904, na revista Arquivo para a Ciência Social e Política Social. Referimo-nos ao pequeno ensaio A Objetividade do Conhecimento nas Ciências Sociais (WEBER, 2008a, p. 79-127), e é deste texto que extrairemos a maior parte das citações de Weber nos próximos parágrafos.
} 


\section{Críticas à Racionalidade Iluminista e ao Hegelianismo}

O diálogo de Max Weber com o Positivismo, ou mesmo com a sua matriz ancestral - o iluminismo do século XVIII - é de todo modo bastante tenso e crítico. Da concepção geral iluminista, berço no qual se formaram os campos de saber que se propuseram a estudar a realidade social, Max Weber irá criticar a exagerada "fé otimista na racionalização teórica e prática do real", que, no contexto de entusiasmo geral da intelectualidade setecentista, terminou por "evitar que fosse descoberto o caráter problemático da perspectiva que ela pressupunha ser evidente" (WEBER, 2008a, p. 101). É contra esta ingênua falácia que Weber dirige os seus alertas, rejeitando frontalmente a possibilidade de que os estudos da realidade social possam alcançar "um conhecimento monista [fundado em um princípio único] de toda a realidade e livre de qualquer 'contingência' individual, sob o aspecto de um sistema conceitual de validade metafísica e forma matemática" (WEBER, 2008a, p. 101). Mais ainda, chama atenção para os efeitos nocivos decorrentes das ilusões iluministas, e depois positivistas, no que concerne à crença ilimitada no progresso técnico, como se este fosse a outra face de uma evolução das ciências naturais e humanas rumo a uma compreensão cada vez mais precisa das leis gerais às quais não escapariam mesmo as sociedades humanas $^{26}$. Aqui, na crítica à noção ingênua de progresso, Weber deixa que reverbere em seu acorde teórico o seu 'harmônico nietzscheniano'27.

A questão da 'subjetividade', por tudo isso, aparece em Weber de maneira bastante complexa. Weber é em parte um neo-kantiano, e, embora não acredite que se possa abordar a Realidade em si mesma, considera possível abordar aquele Real que se oferece de alguma maneira à experiência sensível, precisamente a partir dos aspectos selecionados pelo sujeito de conhecimento de acordo com os direcionamentos impostos pela sua própria subjetividade. O sociólogo alemão utiliza em um de seus ensaios, aliás, uma metáfora que é particularmente esclarecedora para compreendermos tanto o viés neo-kantiano que paira sobre o seu acorde teórico, como para vislumbrarmos a nota fundamental de historicismo relativista que interfere na sua perspectiva sobre as ciências humanas. Os valores e pontos de vista que constituem o complexo de subjetividades inerentes ao pesquisador seriam como que "fontes de uma iluminação especial" que podem ser empregadas para a apreensão de certos aspectos da realidade. Contudo, conforme postula Weber:

A realidade irracional da vida e o seu conteúdo de significados possíveis são inesgotáveis, e também a configuração concreta das relações valorativas mantémse flutuante, submetida às variações do obscuro futuro da cultura humana. A luz propagada por estas idéias de valor supremas ilumina a cada vez, apenas uma parte finita e continuamente modificada, do caótico curso de eventos que flui através do tempo (WEBER, 2008a, p. 126).

26 Referindo-se à conexão iluminista entre o mito evolutivo do progresso técnico e a aproximação metodológica das ciências naturais e sociais, Weber registra, em Objetividade do Conhecimento nas Ciências Sociais (1904), os seguintes comentários: "Qualquer progresso de princípio na formação de leis [de acordo com a concepção de mundo iluminista] era também, e podia sê-lo, um progresso na disciplina prática. Porque, quando os fins permanecem inalteráveis, a redução progressiva de questões práticas (um caso de doença, um problema técnico) a leis de validade geral, e a consequente ampliação do conhecimento teórico, ligam-se à ampliação das possibilidades técnicas e práticas e se identifica com ela" (WEBER, 2008a, p. 101-102). Na mesma sequência, Weber também empreende a crítica da perspectiva evolucionista que no século seguinte surgiu na Biologia e daí se alastrou para todo o conjunto de ciências, inclusive as ciências sociais.

$27 \mathrm{Na}$ mesma sequência antes citada, parece ser evocada, em seguida, uma imagem nietzscheniana, invertida por Weber de modo a produzir um efeito irônico contra o enquadramento de todas as ciências em uma lei geral evolucionista: "Quando a Biologia moderna conseguiu englobar igualmente os elementos da realidade que nos interessam historicamente [...] dentro de um princípio de evolução de validade geral, que pelo menos na aparência - mas não na realidade - permitia ordenar todo o essencial daqueles objetos dentro do conceito de um princípio de evolução de validade geral, dir-se-ia que, sobre todas as ciências, pairava ameaçadoramente o crepúsculo dos deuses de todas as perspectivas axiológicas" (WEBER, 2008a, p. 102). Em tempo, O Crepúsculo dos Ídolos (ou: "como filosofar a golpes de martelo") é o título de uma das mais impactantes obras de Nietzsche (1888). 
Essa sentença, na qual parece ecoar o harmônico nietzscheniano oculto no 'acorde teórico' de Max Weber, é profundamente anti-hegeliana. A menção à "realidade irracional da vida" contrapõe-se à célebre frase de Hegel de que "o real é Racional, e o Racional é Real” (HEGEL, 1997). Todavia cumpre esclarecer, antes de prosseguirmos, o famoso dito de Hegel. Para este filósofo, o "real" e o "existente" não são a mesma coisa. O mundo que existe concretamente, formado por coisas individualizadas - esse mundo que "existe" aos olhos dos seres humanos - é o mundo das aparências. Esse mundo constituído por aparências, e que percebemos como existente, não é o "real" a que se refere Hegel ${ }^{28}$.

Retomemos Max Weber e o trecho mencionado. A frase "os conteúdos de significações possíveis são inesgotáveis" faz lembrar aquele famoso aforismo anti-positivista registrado em 1885 por Nietzsche, segundo o qual "não há fatos, somente interpretações" (WEBER, 1996, p. 1617). Isso certamente contraria, mais uma vez, a superposição hegeliana entre a realidade e a (única) explicação racional possível, e mais ainda a pretensão hegeliana de enxergar o Ser (que é racional) por meio da história e da filosofia da história, a caminho de sua gradual e teleológica tomada de consciência. O "obscuro futuro da cultura humana", evocado por Max Weber, não permite que se tenha em vista nada previsível, ao contrário do destino teleológico propugnado pelo otimismo da 'filosofia da história' de Hegel (1830). O “curso dos eventos" é "caótico", o devir se modifica continuamente, como um irrequieto rio heraclitiano. Puro Nietzsche. Anti-Hegel. Por fim, um desfecho Neo-Kantiano:

\begin{abstract}
É preciso não darmos a tudo isso uma falsa interpretação no sentido de considerarmos que a autêntica tarefa das ciências sociais consiste em uma perpétua caça a novos pontos de vista e construções conceituais. Pelo contrário, convém insistir mais do que nunca sobre o seguinte: servir o conhecimento de significação cultural de complexos históricos e concretos constitui o único fim último e exclusivo ao qual, juntamente com outros meios, está também dedicado o trabalho de construção e crítica de conceitos (WEBER, 2008a, p. 126-127).
\end{abstract}

O Real, na sua totalidade, é inapreensível, e tampouco é apreensível pelos modos de conhecimento relacionados às diversas ciências e práticas humanas tudo o que existe no mundo das aparências. Como diria Kant, sempre existirão aspectos da realidade que jamais poderão se tornar objeto de conhecimento para os seres humanos, que estão necessariamente limitados pelos seus aparelhos sensoriais e pelas subjetividades inerentes aos seus sistemas conceituais ${ }^{29}$.

28 Em Hegel, real é aquilo que tem o Ser em si, sendo inteiramente independente de outro Ser. O "real é”, mas não existe, no sentido habitual desta expressão, e corresponde na verdade aos "universais" (a "leveza", por exemplo, é um universal, mas não um "objeto leve", que já é um particular). O que existe, como por exemplo um objeto individualizado que faz parte deste mundo de aparências, existe apenas como "particular", e na verdade é inteiramente dependente de outro ser.

Este ponto merece esclarecimentos, pois nos leva à distinção entre Kant e Hegel. O problema fundamental filosófico para Kant é o do "conhecer" (e não o do "Ser", como em Hegel). Ambos, Kant e Hegel, acreditam em "universais" (que Kant chama de "categorias"). Mas eis a diferença: para Kant, a realidade em si mesma (a "coisa-em-si") não pode ser conhecida; o mundo, de fato, só pode ser conhecido a partir de dois tipos de categorias: as categorias derivadas da "experiência" (que são assimiladas através dos sentidos, como a "Cor" ou o "Som"), e as chamadas "categorias a priori”, que não dependem da sensibilidade e já existem, na "estrutura da mente", previamente à "experiência". Categorias como "totalidade", "unidade", "diversidade" podem ser utilizadas porque a mente humana já é constituída e organizada de certa maneira, a partir de certas "estruturas" que já existem em todas as mentes humanas, e que as levam a enxergar o mundo de uma certa maneira, a interpor-lhes um filtro que modifica a sua forma de perceber a realidade. Ao lado das categorias sensoriais, as "categorias apriori" obrigam a que enxerguemos o mundo de determinada maneira, sob a forma de suas aparências (fenômenos). A realidade não é percebida, para os kantianos e neo-kantianos, tal como ela realmente é; mas sim através das "categorias" que estruturam a mente e medeiam o processo 
A história, ela mesma, mostra-se parcialmente insondável ao pesquisador e estende-se, para muito além de suas possibilidades de percepção, como uma "caótica e prodigiosa onda de acontecimentos". Regiões inteiras do que um dia foi vivido permanecerão inacessíveis ao conhecimento humano, e outras somente poderão ser acessadas sob os efeitos de uma luminosidade especial que muda de pesquisador a pesquisador, de cultura a cultura, de época para época. Mais do que uma realidade complexa e exuberante que apenas oferece ao homem uma pequena fração passível de ser apreendida, Weber ainda frisa o fato, inpulsionandose para além do neo-kantianismo, de que "[...] apenas uma parte finita da infinita diversidade dos fenômenos é significativa" (WEBER, 2008a, p. 93-94) ${ }^{30}$. Uma realidade que já se oferece ao homem de maneira limitada é acrescida de novas restrições, na medida em que, mesmo de tudo o que é passível de ser conhecido, apenas uma nova fração é significativa. Mais ainda, essa atribuição de significação varia consideravelmente de acordo com as épocas, culturas, escolas de pensamento . Por fim, os próprios valores de cada pesquisador atuam como uma última, mas a mais fundamental, instância de restrições ${ }^{32}$. No entanto, é possível conhecer efetivamente algo. E esta possibilidade de conhecer, continua Weber, parte de uma escolha - uma escolha que é sempre determinada por certos valores subjetivos $^{33}$. Mais ainda, é possível conhecer nas ciências sociais e humanas precisamente por causa dos valores e das intersubjetividades, que deixam de ser obstáculos e passam a ser condições efetivas para a concretização deste tipo de conhecimento ${ }^{34}$.

de conhecimento - categorias que são portanto subjetivas. Desse modo, há para Kant uma distinção entre "conhecer" e "ser" que não existe para Hegel, filósofo para quem os "universais" já estão fora de mente humana, como "condições para o existir", e para quem, consequentemente, o "conhecer" e o "ser" (Razão e Realidade) se superpõem e se equivalem (ressalvada a não coincidência, para Hegel, entre "ser" e "existente", à qual já nos referimos).

${ }^{30}$ Rejeitando a mera descrição de fenômenos, Weber irá atribuir um papel importante para a explicação causal, embora não no sentido mecanicista e linear de alguns dos setores do Positivismo: “[...] só alguns aspectos dos fenômenos particulares infinitamente diversos, e precisamente aqueles a que conferimos uma significação geral para a cultura, merecem ser conhecidos, pois apenas eles são objetos da explicação causal” (WEBER, 2008a, p. 94). O papel da causalidade nas ciências sociais, de acordo com Weber, não é um fim como em certos setores do Positivismo Clássico, mas sim um meio: "Onde quer que se trate de explicação causal de um 'fenômeno cultural' - ou de uma 'individualidade histórica', expressão já utilizada relativamente à metodologia da nossa disciplina, e agora habitual na lógica, com uma formulação mais precisa -, o conhecimento das leis da causalidade não poderá constituir o fim mas antes o meio do estudo" (WEBER, 2008a, p. 94). De fato, Weber chama atenção para o fato de que, "nas ciências da cultura", não teremos "conexões regulares", no sentido estrito das ciências da natureza, mas sim "conexões causais adequadas", o que o permite se contrapor à causalidade mecanicista proposta pelos positivistas nos termos de "possibilidades objetivas" (WEBER, 2008a, p. 95).

31 "O fluxo do devir incomensurável flui incessantemente ao encontro da eternidade. Os problemas culturais que fazem mover a humanidade renascem a cada instante e sob um aspecto, e permanece variável o âmbito daquilo que, no fluxo eternamente infinito do individual, adquire para nós importância e significação, e se converte em 'individualidade histórica'. Mudam também as relações intelectuais sob as quais são estudados e compreendidos. Por conseguinte, os pontos de partida das ciências da cultura continuarão a ser variáveis no imenso futuro, enquanto uma espécie de imobilidade chinesa da vida espiritual não desacostumar a humanidade de fazer perguntas à sempre inesgotável vida" (WEBER, 2008a, p. 100).

32 "Este caos só pode ser ordenado pela circunstância de que, em qualquer caso, unicamente um segmento da realidade individual possui interesse e significado para nós, posto que ele só se encontra em relação com as idéias de valor culturais com que abordamos a realidade" (WEBER, 2008a, p. 94).

33 A metáfora da luminosidade valorativa que "traz a nu" regiões da realidade caótica não deve nos confundir. A tarefa do cientista social, de acordo com a perspectiva weberiana, não é iluminar ou reproduzir através de um sistema de idéias uma realidade objetiva já dada (esse viés estaria mais próximo da concepção de Durkheim). A tarefa do cientista social, para Weber, é criar uma ordem racional para os diversos aspectos da realidade empírica que podem ser apreendidos pela pesquisa. O objeto de conhecimento não é surpreendido pela iluminação da análise, como se já existisse previamente; ele é constituído na própria análise.

${ }^{34}$ Aqui reverbera um discreto harmônico que remonta ao filósofo setecentista Giambattista Vico (1668-1744), e que reaparecerá no século XX em Gadamer (1900-2002) e em toda uma linha hermenêutica de pensadores que fortalecem seu pensamento a partir das vertentes relativistas do Historicismo. Precursor de todos, Vico, em sua Ciência Nova (1725), já alertava para o fato de que só podemos conhecer verdadeiramente - no âmbito de uma perspectiva que envolve a "compreensão" - aquilo do que efetivamente participamos. 


\section{As Diversas Subjetividades}

Escolhido o objeto de estudo pelo sujeito que produz o conhecimento, a partir dos valores que o permitem encontrar interesse em determinados objetos e não em outros, ou que o permitem até mesmo "enxergar" a possibilidade científica destes e daqueles objetos de estudo, o pesquisador também precisará constituir em seguida o seu aparelho conceitual, formular uma problemática, decidir quanto aos materiais a partir dos quais estabelecerá a sua base empírica de investigação (o que, no caso da História, equivale a constituir suas fontes). Cada uma destas ações, a cada instante que se repete, mostra-se novamente interferida pela subjetividade do pesquisador ${ }^{35}$. Como então enfrentar essa invasão de subjetividades em cada momento de sua operação científica? Para que o sujeito de conhecimento consiga ultrapassar de maneira satisfatória os diversos obstáculos oferecidos pela sua própria subjetividade - seus preconceitos, interesses sociais específicos, direcionamentos morais, maneiras prévias de conceber o mundo, "pontos de vista" Weber propõe que se compreenda esta subjetividade, inicialmente, de forma bipartida, pois existiria de um lado uma espécie de subjetividade que favorece o conhecimento científico, e, de outro lado, uma outra espécie de subjetividade que o compromete, e que, portanto, precisa ser descartada ou controlada.

Seria possível falar em um certo padrão de 'subjetividades lógicas' que é útil ao conhecimento científico e às operações lógicas, e em um outro padrão de 'subjetividades práticas' que apenas se mostra útil à vida comum, às esferas política, moral, e outras similares. Cada um dos dois padrões de subjetividade, para Weber, pode ser adequado ou não às várias esferas autônomas do ser humano no exercício das atividades necessárias à sua vida material, social e intelectual. Weber considera necessário, aliás, proceder a uma nova divisão da subjetividade humana em diversas esferas autônomas que teriam cada qual a sua lógica e procedimentos específicos (as esferas política, moral, afetiva, cultural, religiosa, e outras)

$\mathrm{Na}$ subdivisão inicial que procura identificar dois padrões distintos de subjetividade, teríamos, de um lado, uma subjetividade lógica - habilitada a conhecer a sociedade de modo empírico, a apresentar soluções técnicas e a se limitar apenas à produção de "juízos de fato" - e de outro lado o segundo padrão de subjetividade: valorativo, ligado à vida prática e destinado a produzir "juízos de valor". Este último padrão de subjetividade, de acordo com as proposições de Max Weber, atenderia perfeitamente bem às esferas 'afetiva', 'política', 'moral', bem como à 'sociabilidade prática', mas somente o primeiro padrão - o da "subjetividade lógica" - seria adequado à produção do conhecimento científico ou de determinados saberes desenvolvidos pelos homens.

Será oportuno ressaltar que, a certa altura, parecem repercutir na argumentação weberiana os entrechoques produzidos pelas disputas entre as Ciências Sociais e a História que se dão no início do século XX, precisamente naquelas décadas em que Weber escreve os seus livros. Ele relega às Ciências Sociais esta tarefa maior de conhecer a sociedade tal comoela seapresentanos seusdesenvolvimentosmais gerais, inclusive quando lida com temporalidades históricas anteriores, e à História propriamente dita reserva uma reflexão que, de maneira valorativa, já busca um certo "sentido" para a história. $\mathrm{Na}$ verdade, tanto a perspectiva historiográfica como a perspectiva sociológica, tal como Weber as entende, são importantes para este pensador alemão. Em uma - a perspectiva histórica - a atenção volta-se para a singularidade de determinada configuração cultural e social, e para a possibilidade de entendê-la nos termos de um processo que conduziu a ela. Na outra, a perspectiva sociológica, emerge a abordagem comparativa com especial destaque, já que a

\footnotetext{
35 Para uma passagem de Max Weber que sintetiza sua reflexão sobre a interferência dos valores na pesquisa de ciências humanas, ver Weber, (2008a, p. 98).
} 
sociologia histórica de Weber estará atenta para os elementos de uma configuração sócio-cultural que podem ser encontrados em outras épocas e lugares, ou então que possam ser contrastados, produzindo uma iluminação recíproca e que contribua para o esclarecimento das peculiaridades de cada uma das configurações sociais examinadas. De um modo ou de outro, a Sociologia, de acordo com esta perspectiva weberiana, alcança aqui uma dimensão mais geral. Em certa passagem de Condições Agrárias da Antiguidade (1909), apenas para dar um exemplo, podemos surpreender Weber ressaltando que "por vezes fenômenos inteiramente desaparecidos da cultura antiga reaparecem em um mundo que lhes era alheio". Mas é importante destacar que o objetivo final da abordagem comparativa praticada por Weber, ao iluminar duas ou mais configurações históricas específicas, é sempre revelar o que é peculiar e singular a cada uma delas, de modo que, nesse particular, a metodologia comparada vibra por simpatia com a 'nota historicista' do acorde teórico do sociólogo alemão.

\section{Tipos Ideais}

O livre trânsito pelas perspectivas histórica e sociológica também confere ao instrumental metodológico weberiano uma importante riqueza de possibilidades. A metodologia proposta por Weber, conforme já se disse, envolve tanto a análise qualitativa, em função da singularidade do fragmento de realidade examinado, como também a identificação de regularidades, modelos, tipos. São famosos os seus "tipos ideais", um recurso metodológico de acordo com o qual o cientista social irá elaborar, como construção compreensiva, um modelo abstrato que na verdade só existe no processo de produção do conhecimento, não coincidindo exatamente com a realidade, mas dela se aproximando e sintetizando seus aspectos essenciais. O tipo ideal, portanto, não é o objetivo final, mas apenas um meio ou recurso para elaboração do conhecimento; não se trata, enfim, de uma realidade histórica, mas sim de um horizonte de pensamento construído para se aproximar desta realidade empírica. O próprio Max Weber, em seu texto sobre A Objetividade do Conhecimento nas Ciências Sociais (1904), esclarece o que seria, basicamente, o "tipo ideal":

Obtém-se um tipo ideal mediante a acentuação unilateral de um ou vários pontos de vista, e mediante o encadeamento de grande quantidade de fenômenos isoladamente dados, difusos e discretos, que se podem dar em maior ou menor número ou mesmo faltar por completo e que se ordenam segundo os pontos de vista unilateralmente acentuados, a fim de se formar um quadro homogêneo de pensamento (WEBER, 2008a, p. 106).

O "tipo ideal" é, portanto, uma abstração útil, intuída em um primeiro momento a partir de certos indícios da realidade empírica, e ao mesmo tempo aproximativa em relação à realidade ou ao que se pensa ser, por hipótese, a realidade social a ser examinada. Trata-se, sobretudo, de um recurso para ser instrumentalizado durante a pesquisa, e para ser ou não incorporado, depois de eventuais reajustes, à exposição final estabelecida pelo texto a ser produzido pelo cientista social ou pelo historiador. Podemos entender o que pretendeu Max Weber com a criação deste recurso metodológico, e também compreender como este recurso pode ser utilizado nas pesquisas e reflexões dos sociólogos e historiadores atuais, se tivermos igual clareza sobre o que o tipo ideal não é.

O próprio Max Weber é explícito a este respeito: o tipo ideal não é uma hipótese, mas sim um recurso que "pretende apontar o caminho para a formação de hipóteses" (WEBER, 2008a, p.

\footnotetext{
34 "Mas quem ainda tem dúvidas quanto ao que quero quanto às três exigências a que desta vez minha ira, minha preocupação, meu amor à arte deram voz? Que o teatro não se torne senhor das artes.Que o ator não se torne sedutor dos autênticos. Que a música não se torne uma arte da mentira" (NIETZSCHE, 1999b, p. 33).
} 
106). Tampouco o 'tipo ideal' é uma média ${ }^{36}$. Na verdade, o tipo ideal é o substituto compreensivo para uma realidade extremamente difusa, cuja descrição exaustiva e minuciosa, à parte o fato de ser obviamente impossível, resultaria em uma descrição caótica, eivada de contradições, habitada não por um padrão reconhecível, mas apenas pelos desvios deste padrão, uma vez que o que realmente existe são precisamente os desvios (isto é, as singularidades e as versões individuais para certa tendência cultural que inexiste no seu estado puro) $)^{37}$.

Este ponto merece algumas considerações. Conforme já ressaltamos, Weber está longe de ser um hegeliano. Para ele, o Real não é Racional, e o Racional não é Real, como queria Hegel $^{38}$. Ao contrário, parece reverberar na percepção weberiana do mundo um "harmônico nietzscheniano". Weber reconhece que o mundo é complexo, ou mesmo caótico; chega a utilizar a palavra "caos" algumas vezes, e em certa ocasião menciona a "realidade irracional da vida" (WEBER, 2008a, p. 126). Não se trata nem mesmo de desvendar a realidade por trás do mundo das aparências, ou nele manifesta. A realidade vivida - este existir histórico que é o que realmente interessa a Max Weber como estudioso do humano - corresponde a um devir extremamente mutável, a forças diversas que se embatem, a singularidades que se afirmam. Essa visão do mundo históricosocial bem que permitiria um ponto de contato com a visão filosófica de Nietzsche a respeito do mundo e, por isso, utilizamos a metáfora de que o "harmônico Nietzsche" reverbera de alguma maneira no 'acorde teórico' de Max Weber ${ }^{39}$.

Contudo, a resposta que Weber dá a esta realidade que percebe como extremamente mutável, conflituosa, e mesmo caótica, é radicalmente distinta da resposta de Nietzsche, que pretende a cada instante chamar atenção para as descontinuidades. Max Weber, um espírito francamente sistematizador e tocado por um temperamento inclinado à racionalização, tenderá a atribuir ao pesquisador-pensador a tarefa de criar uma ordem teórica para o caos. O Real não é Racional, e o Racional não é Real. E o que existe não é expressão de uma ordem subjacente. Mas isto não impede que a realidade caótica seja racionalizada, compreendida de uma forma sistemática por aqueles que a pensam, mesmo que a cada momento esta sistematização precise ser reelaborada, o que, aliás, será tarefa diuturna de cada um que se dedique ao estudo da sociedade, ou mesmo, em um arco mais amplo, de cada época científica que dará a tonalidade de uma nova fase da história do conhecimento ${ }^{40}$.

\footnotetext{
36 Max Weber dá o exemplo das formações urbanas medievais, na história mais ampla das cidades na Europa Ocidental (assunto a que ele se dedicou com especial atenção, e cujos resultados aparecem em Economia e Sociedade). A construção conceitual que permite falar em uma "economia urbana medieval" não pode ser obtida pelo "estabelecimento de uma média dos princípios econômicos que realmente existiram em todas as cidades examinadas", mas antes, "é pela construção de um tipo ideal que, neste último caso, se forma o conceito de "economia urbana"” (WEBER, 2008a, p. 106).

37 “As ‘idéias' que dominaram os homens de uma época, isto é, as que neles atuaram de forma difusa, só poderão ser compreendidas, sempre que formem um quadro de pensamento complicado, com rigor conceitual, sob a forma de um tipo ideal, pois empiricamente elas habitam as mentes de uma quantidade indeterminada e mutável de indivíduos, nos quais estavam expostas aos mais diversos matizes, segundo a forma e o conteúdo, a clareza e o sentido" (WEBER, 2008a, p. 111). Em seguida a estes comentários, Max Weber oferece exemplificativamente o caso do "cristianismo medieval". Descrever o que seria isso de fato implicaria em trazer à tona "um caos de relações intelectuais e de sentimentos de todos os tipos, infinitamente diferenciados e extremamente contraditórios" (WEBER, 2008a, p. 111).

38 A célebre frase hegeliana de que "o real é Racional, e o Racional é Real", à qual já nos referimos, aparece pela primeira vez na obra Princípios da Filosofia do Direito (HEGEL, 1997).

${ }^{39}$ Naturalmente que a percepção weberiana do devir histórico não está isenta de ambigüidades. Ele deixa entrever em diversas oportunidades que, para uma civilização como a do Ocidente, seria possível falar nas diversas tendências de pensamento e sensibilidade correspondentes a cada época. Sua análise comparada da Cidade termina por construir 'tipos ideais' para a Cidade Antiga, a Cidade medieval, a Cidade Moderna.

40 "Numa época de especialização, qualquer trabalho nas ciências da cultura, após ter-se orientado para determinada matéria através
} 
O 'tipo ideal' não existe efetivamente no seu estado puro, pois o que de fato existe em uma realidade histórico-social é um imenso e caótico repertório de variações e desencaixes que mais poderiam ser percebidos como "desvios" do que como "confirmações" do "tipo ideal". Essa consideração leva-nos a este alerta final de que o tipo ideal não é a realidade. Tal como salienta Max Weber, é mesmo impossível encontrar na realidade histórica - "em sua pureza conceitual" - o quadro fornecido pelo tipo ideal, e a atividade dos historiadores deve se defrontar precisamente com "a tarefa de examinar, em cada caso particular, a proximidade ou afastamento entre a realidade e o quadro ideal" (WEBER, 2008a, p. 101) ${ }^{41}$. De outra parte, alguns historiadores e sociólogos também podem e devem criar novos tipos ideais para submetê-los a novas investigações empíricas, e isto será de fato um trabalho incessante daqueles que procuram compreender as realidades sociais.

Há ainda uma questão delicada acerca do que não deve ser o tipo ideal. Se por um lado o tipo ideal é assumido como uma abstração - isto é, como uma representação que não coincide com a realidade, mas que dela busca se aproximar - essa abstração precisa estar efetivamente ancorada em indícios, sinais ou sintomas da realidade que se pretende examinar. Dessa maneira, a construção do tipo ideal pressupõe uma pesquisa prévia, uma demorada reflexão sobre elementos e o contexto que realmente constituem a realidade a ser examinada, e, no caso da História, um olhar mínimo e prévio sobre as fontes que depois serão examinadas em maior profundidade. Além disso, a construção do tipo ideal impõe a necessidade de uma atualização, de uma construção permanente à medida que se avança na apreensão de novos elementos; em uma palavra: flexibilidade. Isto porque, se o tipo ideal for construído como abstração desencarnada que precede totalmente a pesquisa, e que ainda por cima pretende se impor à análise social de maneira demasiado rígida sem admitir ajustes posteriores, corre-se o risco de forjar uma realidade conceitual desencaixada, à qual mais tarde os elementos empíricos terão de ser adaptados de maneira mutiladora, forçando a realidade empírica a se enfiar em uma espécie de "leito de Procrusto"42.

do seu modo determinado de colocar os problemas, e uma vez adquiridos os seus princípios metodológicos, verá na elaboração dessa matéria um fim em si mesmo, sem controlar continuamente e de forma consciente o valor cognitivo dos fatos isolados pela sua referência às idéias de valor últimas e mesmo sem tomar consciência da sua ligação com essas idéias de valor. E é bom que assim seja. Mas um dia torna-se incerto o significado dos pontos de vista adotados irrefletidamente, o caminho perde-se no crepúsculo. A luz dos grandes problemas culturais deslocou-se para mais além. Então a Ciência prepara-se também para mudar o seu cenário e o seu aparelho conceitual, e fitar o fluxo do devir das alturas do pensamento. Ela segue a rota dos astros que unicamente podem dar sentido e rumo ao seu trabalho" (WEBER, 2008a, p. 127).

${ }^{41}$ Seguindo com o mesmo exemplo das cidades medievais, Max Weber argumenta que será precisamente a tarefa dos historiadores a de verificarem "em que medida o caráter econômico das condições de determinada cidade poderá ser qualificado como 'economia urbana' em sentido conceitual” (WEBER, 2008a, p. 106). Afinal, entre as inúmeras formações urbanas medievais algumas poderão ou não corresponder ao conceito de "economia urbana", e mesmo não serem consideradas autênticas cidades de acordo com esta perspectiva. Para conhecer o conceito e categorias da cidade propostas por Max Weber, ver toda a 'seção 7' de Economia e Sociedade (WEBER, 1999, p. 408-517).

${ }^{42}$ Procrusto era um salteador da antiga mitologia grega que costumava receber em sua casa, situada em uma floresta nas proximidades de uma estrada, viajantes cansados que pediam acolhida antes de seguir viagem. O bandido havia construído uma cama de ferro (o "leito de Procrusto"). Ao encontrar um viajante desavisado, Procrusto oferecia sua falsa hospitalidade, servia-lhe um bom jantar e o embebedava. Em seguida, estendia o viajante no leito de ferro, que em geral era menor ou maior do que o corpo da vítima. Ao ajustar a cabeça do viajante ao catre da cama, podia se dar que este fosse maior que o leito e que os pés ultrapassassem, do outro lado, o pé da cama. Procrusto então os cortava fora, de modo que o corpo do viajante se visse rigorosamente ajustado ao leito. Se, porém, o corpo do viajante era menor do que o leito, Procrusto também costumava fazer o seu ajuste, desconjuntando os pés da vítima de modo que, nesta nova forma mutilada, tanto a cabeça se ajustasse ao catre, como os pés se ajustassem à outra borda do leito. Conta o mito que Procrusto morreu nas mãos do herói Teseu, ao tentar submetê-lo a esta prática, e que o herói decidiu aplicar-lhe o mesmo fim que sempre havia imposto às suas vítimas. $\mathrm{O}$ mito procura representar as situações em que já se tem um modelo previamente construído para, a partir daí, adaptar-lhe a todo custo a realidade empírica que se pretendia examinar. Max Weber vale-se da metáfora do "leito de Procrusto" em A Objetividade do Conhecimento nas Ciências Sociais (1904), ao se referir aos quadros conceituais demasiados rígidos dentro dos quais “a História deverá ser introduzida à força” (WEBER, 2008a, p. 110). 
Weber utiliza esta metáfora para enfatizar o fato de que uma construção teórica, seja um tipo ideal ou um quadro conceitual, é sempre um meio, mas nunca um fim ao qual a realidade deve se ajustar de maneira forçada e a todo custo.

Posto isto, voltemos à questão da não coincidência rigorosa entre o 'tipo real' e a realidade, uma vez que ela tangencia outra questão importante, à qual Weber também se refere. Se cada pesquisador ou cientista social seleciona fragmentos da realidade empírica em função de seus próprios valores, e também decide o seu quadro teórico e repertório de problemas a partir destes mesmos valores, ocorre que um pesquisador ou pensador sempre produzirá seu trabalho de modo diferente de outro pesquisador que investigasse uma temática análoga. A construção de um tipo ideal que vise a uma determinada realidade ou problemática, portanto, pode se constituir em experiência única para cada cientista social. Inúmeros "tipos ideais" poderiam ser construídos em torno de uma mesma temática ou questão de estudo:

Do mesmo modo que existem os mais diferentes 'pontos de vista', a partir dos quais podemos considerar como significativos os fenômenos citados, pode igualmente fazer-se uso dos mais diversos princípios de seleção para as relações suscetíveis de serem integradas no tipo ideal de uma determinada cultura (WEBER, 2008a, p. 107).

O tipo ideal corresponde sempre a uma construção da imaginação do pesquisador, e não a um "exemplar" que deve "ilustrar" necessariamente à realidade; menos ainda, o tipo ideal será um exemplo extraído diretamente de uma lei que já havia sido deduzida antes. Posto isto, ainda que o tipo ideal e a realidade não se superponham, essa construção teórica deve ser, em todo o caso, “objetivamente possível” (WEBER, 2008a, p. 107). Neste aspecto em particular Max Weber passa ao largo da perspectiva positivista e se aproxima muito mais do Historicismo. De todo modo, acompanhando o que já dissera sobre a formulação provisória de "leis" nas ciências sociais - sempre um meio, e nunca um fim - Max Weber sempre estará igualmente frisando que o "tipo ideal" só adquire importância para as ciências que estudam a realidade social se for tratado como um "meio", e nunca como um "fim" que termina por se tornar o próprio objetivo e ponto de chegada da pesquisa. O tipo ideal, visto desta maneira, deve interessar muito pouco ao Positivismo clássico, mas pode ser extremamente útil na mão dos historicistas (e, porque não acrescentar, dos materialistas históricos) $)^{43}$.

\section{Exemplo de Aplicação dos Tipos Ideais}

Um dos exemplos mais notórios de aplicação dos tipos ideais, conforme veremos, pode ser encontrado no livro A Ética Protestante e o Espírito do Capitalismo, (1904-5), no qual Weber relaciona estes dois tipos ideais e os coloca em interação. Esta obra emblemática dá-nos adicionalmente a oportunidade para discorrer sobre o fato de que outra 'nota metodológica' importante no 'acorde Weber' é precisamente a perspectiva de que a análise sociológica deve partir sempre dos "agentes" (indivíduos envolvidos em uma "ação social"). Se, em Weber, são autônomas e dotadas

\footnotetext{
${ }^{43}$ Quem for da opinião de que o conhecimento da realidade histórica deveria, ou poderia ser uma cópia 'sem pressuposições' de fatos 'objetivos', negar-lhes-á [aos tipos ideais] qualquer valor. E mesmo quem tiver reconhecido que, no âmbito da realidade, nada está isento de pressuposições em sentido lógico, e que o mais simples extrato de atas ou documentos apenas poderá ter algum sentido científico em relação a 'significações' e assim, em última análise, em relação a idéias de valor, considerará no entanto a construção de qualquer espécie de 'utopia' histórica [outra palavra de Weber para 'tipo ideal'] como um meio ilustrativo perigoso para a objetividade do trabalho científico, e com mais freqüência, como um simples jogo. E, de fato, nunca se poderá decidir a priori se se trata de mero jogo mental, ou de uma construção conceitual fecunda para a ciência. Também aqui existe apenas um critério, o da eficácia, para o conhecimento de fenômenos culturais concretos, tanto nas suas conexões como no seu condicionamento causal e na sua significação. Portanto a construção de tipos ideais abstratos não interessa como um fim, mas única e exclusivamente como meio do conhecimento (WEBER, 2008a, p. 108).
} 
de "legalidades" específicas cada uma das diversas esferas sociais - a economia, a política, a religião, a esfera jurídica, a esfera da criação artística, entre outras - não é senão o "agente" aquele que se pode oferecer como ponto de confluência das várias esferas. $\mathrm{O}$ agente é o ser humano históricoconcreto que expressa a sua orientação social, de múltiplas maneiras, na sua própria trajetória vivida e em uma realidade extremamente complexa que o situa como partícipe de diversificados processos. Somente por meio da análise do agente e de suas ações sociais podem ser percebidas, para cada momento ou configuração histórico-social, as formas de interação entre as diversas esferas, as tensões que entre elas se estabelecem, os encaixes e desencaixes, os ajustes e contradições entre as diversas formas de racionalidade e de "legalidade" que são próprias a cada uma das esferas. Além disso, se o agente é aquele que participa das várias esferas e que, portanto, pode ser constituído como objeto de análise, é também aquele que é capaz de conferir "sentido" às ações sociais.

EmAÉtica Protestante e o Espírito do Capitalismo (1905), Max Weber procura examinar as afinidades e tensões entre o "sentido da ação religiosa" (a Ética Protestante, neste caso) e o "sentido da ação econômica" (o Espírito do Capitalismo). Duas esferas autônomas - a política e a economia - irão encontrar nos "agentes" examinados o seu encaixe, o ponto de confluência no interior do qual poderemos ver aflorarem mútuas afinidades entre as duas esferas, e mesmo o estabelecimento de uma certa relação de causalidade que faz como que o Espírito do Capitalismo derive de uma Ética Protestante, isto é, de uma certa forma de conduta relacionada a um contexto histórico-social específico.

Como apreender através deste agente que é partícipe de múltiplos processos, e encontra-se mergulhado na "onda caótica dos acontecimentos", aquilo que interessa à questão constituída pelo Sociólogo ou pelo Historiador? É aqui que se afirma, mais uma vez, a especial utilidade do recurso aos "tipos ideais". O tipo ideal”, como já se disse, é uma abstração que procura se aproximar da realidade, e que seleciona e organiza os elementos empíricos da realidade em torno de uma questão específica. $\mathrm{O}$ exagero de características é elevado aqui ao estatuto de artifício metodológico. Desta maneira, o "tipo ideal", embora não coincida com a realidade, procura se aproximar desta realidade como uma construção teórica que se mostra capaz de mediar alguns dos inúmeros "agentes" a partir de características em comum. Menos ou mais intensamente, mais convictamente ou menos apaixonadamente, existe um conjunto de agentes que parece partilhar características ou tendências que Max Weber reúne neste tipo ideal que é a "Ética Protestante". Certa conduta recorrente, a ser investigada pelo pesquisador em suas fontes, parece habilitá-lo a falar neste tipo ideal. Sem perder de vista que está trabalhando com uma construção teórico-metodológica, o pesquisador habilita-se aqui a compreender uma dada realidade através do tipo ideal.

O tipo ideal, portanto, revela-se como um eficaz recurso que permite harmonizar a análise sociológica individualizada, que precisa apreender o agente na sua singularidade, e as regularidades sociais que podem ser percebidas. Se a ação social é produzida por agentes específicos, existem determinadas ações que parecem se repetir no tempo e em condições similares. Da mesma maneira, quando certo número de agentes compartilha um mesmo sentido atribuído a determinadas ações sociais, torna-se possível falar em uma "relação social", um conceito que também é empregado com freqüência por Max Weber ${ }^{44}$.

No limite, conforme Weber sustentará em seu ensaio sobre A Objetividade do Conhecimento nas Ciências Sociais (WEBER, 2008a, p. 109), todos os conceitos que podem ser empregados nas ciências humanas são, à sua maneira, tipos ideais: não haveria nem possibilidade nem interesse de que os conceitos utilizados pelos historiadores, por exemplo, fossem tão precisos como os conceitos a serem utilizados nas ciências naturais e físicas. 


\section{Sociologia e História}

A percepção atenta do jogo de singularidades e recorrências delineia-se como outra nota metodológica importante para o acorde de abordagens weberianas. Se a realidade apresentase como um oceano de singularidades, ela também se mostra atravessada por recorrências. A Sociologia, tal como a delineia Max Weber, teria por finalidade examinar estas recorrências, enquanto à História ficaria relegada a finalidade de examinar aquilo que é singular. Obviamente que estamos aqui em um período que antecede a profunda revolução historiográfica que logo seria trazida por contribuições várias, como a da história serial proporcionada pela Escola dos Annales, ou como as análises sociais trazidas pelos novos marxismos. Esse tipo de divisão de trabalho entre a Sociologia e a Historiografia dificilmente poderia ser aceito pela maior parte dos historiadores das décadas que se sucederam à morte de Max Weber. De todo modo, a incorporação pela História de objetivos que os sociólogos reivindicavam para si no início do século também explica a assimilação crescente de Max Weber pela historiografia. A incorporação historiográfica do estudo daquilo que se repete e permanece assegurou a Max Weber um lugar teórico importante entre os historiadores, já desde a década de 1930. Mas novas possibilidades de assimilar Max Weber estariam por vir.

O espectro renovado de Max Weber, se é que podemos utilizar esta imagem, tem adentrado a historiografia através de inúmeras portas. A partir de algumas correntes historiográficas que começam a se afirmar nos anos 1980, ouviremos falar cada vez mais falar em alguns retornos: o "retorno da narrativa", o "retorno da política", o "retorno do indivíduo". Uma perspectiva de análise social que reconhece a importância do indivíduo, e que até postula que a análise parta dos agentes sociais, tende a ser valorizada em um universo historiográfico que também passa a incluir abordagens como a da Micro-História. O próprio "retorno de Max Weber" compreende este autor como um clássico que já é já referência para a historiografia e tem possibilitado aos historiadores constantes reapropriações e releituras, por isso esse retorno constitui uma recorrência em diversos momentos da historiografia.

\section{Conclusão}

Já próximos do desfecho, podemos nos perguntar pela posição teórica weberiana diante do enigma da contradança entre objetividade e subjetividade nas ciências humanas. Será preciso fazer concessões à busca positivista pelo "puro fato", ou entregar-se ao entretecer de interpretações sobre interpretações que se dá no limite extremo do historicismo relativista, quando este já quase ameaça deslizar para o ceticismo ou para a libertação nietzscheniana? Max Weber, um estudioso do budismo, parece propor "o caminho do meio" ${ }^{\prime 45}$

Quase ao fim do seu ensaio sobre A Objetividade do conhecimento nas Ciências Sociais (1904), ele registra este elogio ao equilíbrio do historiador Leopold Von Ranke:

[...] na nossa disciplina, também existem cientistas que 'cultivam a matéria' e outros que 'cultivam o espírito'. $\mathrm{O}$ apetite dos primeiros, ávido de fatos, apenas se sacia com massas de documentos, com tabelas estatísticas

${ }^{45} \mathrm{O}$ "Caminho do Meio" (em sânscrito: Madhyama Pratipad) é uma das mais tradicionais expressões budistas; tratase da estrada eqüidistante aos dois extremos, que se oferece àqueles que se propõem a dar seus primeiros passos em direção à Sabedoria ou, ao menos, em direção ao alívio de seus conflitos. Diz a tradição budista que Buda, certa feita, chegou a desmaiar de fome devido a seu rigoroso jejum. Somente recuperou a consciência quando foi alimentado por uma camponesa que passou perto do lugar onde jazia desacordado. Após meditar sobre este acontecimento, Sidarta term então optou por seguir um "caminho do meio" - um caminho cuidadosamente eqüidistante dos extremos do rigor absoluto e d inou por concluir que o excessivo rigor é tão danoso e ineficaz em termos espirituais quanto a excessiva indulgência, e a partir de a liberdade sem regras. 
e sondagens, mas revela-se insensível aos manjares delicados da idéia nova. O requinte gustativo dos segundos chega a perder o gosto pelos fatos através de constantes destilações de novos pensamentos. O virtuosismo legítimo que, entre os historiadores, Ranke possuía em tão elevado grau, costuma manifestar-se precisamente pelo poder de criar algo de novo através da referência de certos fatos conhecidos a determinados pontos de vista, igualmente conhecidos (WEBER, 2008a, p. 127).

Terá sido Max Weber realmente bem sucedido nas soluções que deu aos problemas da Objetividade e da Subjetividade na produção de conhecimento no âmbito das Ciências Humanas? Qualquer julgamento acerca da eficácia de suas proposições estará sempre em aberto. Hans-Georg Gadamer (1900-2002), um filósofo inserido na grande tradição da Hermenêutica historicista, sustentará que, na sua "ascese metodológica", Weber não teria tido senão êxito em "contornar os problemas do Historicismo" (GADAMER, 2008, p. 451). A contribuição de Max Weber para a Teoria das Ciências Sociais, e os inúmeros estudos históricos e sociológicos através dos quais ele se empenhou em colocar em prática suas propostas teóricas, certamente sempre impressionarão os estudiosos de história das ciências pela sua integração em uma prodigiosa arquitetura intelectual. Muitos, mesmo em campos paradigmáticos adversos às soluções weberianas, não hesitarão em registrar respeito e admiração pelo conjunto das realizações de Weber no decurso de sua trajetória intelectua ${ }^{46}$. Outros, ainda, chamarão atenção para a "notável coerência de sua obra"
$\left(\mathrm{COHN}, 2008\right.$, p. 10) ${ }^{47}$. Historicistas e Positivistas não cansarão de convocar a contribuição teóricometodológica de Weber para o seu próprio campo paradigmático. Max Weber, enfim, conquistou a posição de um clássico.

\section{Referências}

$\mathrm{COHN}$, Gabriel. Crítica e resignação: fundamentos da Sociologia de Max Weber. São Paulo: T. A. de Queiroz, 1979.

COHN, Gabriel. Weber: sociologia. 7. ed. São Paulo: Ática, 2008.

GADAMER, Hans-Georg. Verdade e método. 9. ed. Petrópolis: Vozes, 2008.

HEGEL, Friedrich. Principios da filosofia do direito. São Paulo: Martins Fontes, 1997.

LÖWITH, Karl. Max Weber e Karl Marx. São Paulo: Hucitec, 1994. (Original 1933).

LÖWY, Michael. As aventuras de Karl Marx contra o Barão de Münchhausen. São Paulo: Cortez, 1994.

NIETZSCHE, Friedrich. O crepúsculo dos ídolos. São Paulo: Companhia das Letras, 2006.

OWEN, David. Maturity and modernity: Nietzsche, Weber, Foucault and the ambivalence of reason. New York: Routledge, 1994.

PARSONS, Talcott. Value-freedom and objectivity. In: STAMMER, Otto (Org.). Max Weber and sociology today. London: Harper, 1971. p. 34-48.

\footnotetext{
46 Michael Löwi, sociólogo brasileiro que fará a crítica do modelo weberiano a partir de uma perspectiva marxista, registra as seguintes palavras elogiosas a respeito de Max Weber: "A Wissenschaftsleher de Weber é um edifício imponente, cuja arquitetura rigorosa e coerência lógica impõem o respeito e a admiração. Não é por acaso que ele serve de ponto de referência obrigatório para toda tentativa séria de fundamentar ou refutar a tese da neutralidade axiológica das ciências sociais (os positivistas vulgares se contentam em repetir fastidiosamente as velhas receitas de Durkheim). Esta arquitetura não comporta nenhuma fissura lógica; é apenas se situando em um terreno externo à lógica abstrata de sua demonstração que se pode descobrir a falha nessa formidável couraça metodológica. É a partir de uma perspectiva de sociologia do conhecimento que se revela o calcanhar de Aquiles da teoria weberiana da ciência" (LÖWI, 2009, p.47).

47 "Permitem [os textos de Max Weber] constatar a notável coerência de sua obra, na qual os temas e o modo de tratá-los vão ganhando forma ao longo dos anos, mas já estão claramente delineados nos seus primeiros trabalhos" (COHN, 2008, p. 10). Concordando com Gabriel Cohn, acrescentaremos que Max Weber é destes autores que apresentam uma produção intelectual para a qual poderíamos utilizar a metáfora do acorde que permanece sempre o mesmo na sua tríade fundamental, mas que vai agregando novas notas no decorrer da trajetória intelectual de seu autor, o que resulta em um gradual enriquecimento de tópicos e elementos que não deixa jamais de reforçar a consistência e coerência de um poderoso sistema de pensamento em construção. Max Weber não parece ter produzido rupturas em relação a si mesmo.
} 
RICKERT, Heinrich. Ciencia cultural y ciencia natural. Madrid: Calpe, 1922. (Original 1899).

VICO, Giambattista. Scienza nuova. Milão: Opere, 1953. (Original 1725).

WEBER, Max. A ciência como vocação. In:

Metodologia das ciências sociais. São Paulo: Cortez, 1993. Parte II. (Original 1919).

- Ciência e política: duas vocações. São Paulo: Martin Claret, 2009.

. Economia e sociedade. Brasília: Ed. UNB, 1999.

- A ética protestante e o espírito do capitalismo. São Paulo: Pioneira, 1996. (Original 1904-1905, complemento em 1920).

- A objetividade do conhecimento nas ciências sociais. In: COHN, Gabriel. Weber: sociologia. 7. ed. São Paulo: Ática, 2008a. p. 79127.

A objetividade do conhecimento nas ciências sociais. São Paulo: Ática, 2006. (Original 1904).

. As causas sociais do declínio da cultura antiga. In: COHN, Gabriel. Weber: sociologia. 7. ed. São Paulo: Ática, 2008b. p. 37-57. (Original 1896).

. Essais sur la theorie de la science. Paris: Plon, 1965. (Original 1904-1917).

- História agrária romana. São Paulo:

Martins Fontes, 1994. (Original 1891).

. O estado nacional e a política econômica. In: COHN, Gabriel. Weber: sociologia. 7. ed. São Paulo: Ática, 2008c. p. 58-78. (Original 1895).

. Os fundamentos racionais e sociológicos da música. São Paulo: EDUSP, 1995.(Original 1911).

Recebido em: setembro de 2010

Aceito em: novembro de 2010 
